\title{
OS NOVOS QOM: A CONSTITUIÇÃO DE UMA IDENTIDADE RELACIONAL EM DEVIR*
}

Carlos Salamanca

\section{Apresentação}

Dentre os indígenas que habitam atualmente a região do Chaco argentino, os Toba (qom ${ }^{1}$ ) da região Centro-oriental são os que mais se comprazem em demonstrar sua capacidade para dialogar com o mundo dos brancos, em integrar-se a ele e dele tirar o melhor proveito. Criticados por seus vizinhos indígenas e brancos por sua tendência a "querer ser" ou a "agir" como os brancos, os Toba não percebem como problemática uma identidade coletiva tão plástica como aparentemente contraditória.

Propomo-nos a demonstrar que as diferenças "internas" entre as parcialidades toba são inerentes ao seu processo histórico de constituição, e que eles sempre foram inclinados a integrar a influência "externa" na constituição de sua subjetividade. Através da análise da experiência dos Toba na conquista da cidadania, da terra e do evangelismo indígena (o Evangelho), mostraremos como a identidade coletiva, ainda que diversa e heterogênea, se estabelece através de eixos específicos nos quais as diferenças são mais de intensidade do que de sentido.

Em seguida, nos referiremos à instalação, na década de 1960, de um grupo de famílias toba na periferia da cidade de Formosa. Centrando-nos na concepção toba de agência ou capacidade de ação, analisaremos as múltiplas perspectivas de relação com os brancos no tocante a terra, ao Evangelho e à cidadania que surgem a propósito do aparecimento do bairro. Finalmente, tentaremos demonstrar que, para uma subjetividade em devir, a relação dos Toba com os brancos é, por princípio, fundamental para a constituição de si mesmos.

\section{As múltiplas formas do diferente}

A conquista do atual "Chaco argentino" iniciou-se no começo do século XVIII 
à procura de prata, de caminhos que comunicassem os Andes e Assunção e de almas e fiéis a Deus e aos reis, seus representantes. Foi somente em fins do século XIX que a recém-consolidada nação argentina conseguiu essa conquista através de sucessivas expedições militares entre 1884 e 1911. Os primeiros anos do século XX testemunharam a constituição do Chaco, até então considerado diabólico e rebelde, como palco da utopia nacionalista. Soberania e produtividade legitimaram a declaração das terras indígenas como fiscais, o monopólio estatal sobre elas e sua posterior entrega a proprietários privados.

Até a terceira década do século XX, a diversidade nos graus e nas formas de avanço da fronteira agrícola e das relações econômicas produziram relações díspares entre índios e colonos que combinavam, tendo a violência como denominador comum, a marginalização, a negociação e a subjugação. Durante as três primeiras décadas do século XX, as políticas de colonização, longe de se restringirem a um projeto homogêneo de marginalização dos índios, foram orientadas para facilitar sua exploração econômica. Expulsos de seus territórios, os indígenas chaquenhos enfrentaram também um radical processo de sedentarização.

Antes da colonização, a organização social dos Toba caracterizava-se pela existência de unidades sociais bilaterais constituídas a partir da união de várias famílias extensas, cujos membros estavam inscritos em uma "trama muito clara de alianças que incluíam, por consanguinidade ou por aliança, todos ou quase todos os seus membros" (Cordeu \& de los Ríos 1982:163). Essas unidades nomadizavam ao ritmo dos ciclos ecológicos em territórios relativamente definidos. Parcialidades mais extensas, tradicionalmente denominadas pela etnografia chaquenha de "tribos", eram, pelo contrário, unidades políticas que agrupavam várias das unidades citadas em torno de uma mesma língua e de relações de parentesco por meio do intercâmbio matrimonial (Cordeu \& de los Ríos 1982:163; Braunstein 1983:24). ${ }^{2}$

Todas as unidades sociais viram-se alteradas, de uma forma ou de outra, pelos processos de colonização, que influíram em suas dimensões territoriais, suas dinâmicas políticas, suas formas de constituição e seus elementos de coesão. Para exemplificar brevemente lembremos que: (i) a introdução do cavalo no final do século XVII produziu a extensão do seu domínio territorial e de sua capacidade militar; (ii) às expedições militares levadas a cabo até meados do século XIX os Toba responderam com o aumento de sua capacidade de solidificar coesões internas; (iii) a redução dos territórios de uso e a pressão da fronteira agrícola desde meados do século XIX geraram, além de alianças, conflitos entre diferentes parcialidades; (iv) a partir da experiência de relação com os brancos, os Toba incorporaram como elemento 
fundamental da legitimidade de suas lideranças o respaldo institucionalizado dos brancos; (v) as antigas parcialidades toba acomodaram seus ritmos de expansão e isolamento, segundo os calendários ecológicos e os rituais, aos ritmos do trabalho sazonal nas fazendas e nos engenhos.

Entre os atuais Toba do centro-leste chaquenho existem referências às diferentes "tropilhas" ou "raças", tal como são denominadas atualmente as antigas parcialidades ou bandos de que provêm. As diferenças entre os bandos existiam a partir de vários elementos. Havia, por exemplo, aqueles de caráter geográfico, segundo a proveniência das parcialidades: os sheu-l'ec ("habitantes do norte"), os dapiguem-l'ec ("habitantes do oeste"), os lañagashec ("habitantes do sudeste") e os collaxa-l'ec ("habitantes do sul"). Além da localização espacial, esses grupos se diferenciavam por variações dialetais que podiam coincidir em um mesmo grupo. Em função das características físicas ou dos comportamentos de seus membros, as antigas parcialidades operavam também uma caracterização intersubjetiva sobre a base do conhecimento etológico e a continuidade ontológica entre animais e humanos.

Victoriano de San Carlos afirma, por exemplo, sobre os piolpi que - assim como os cachorros (pioq) - "se zangam e se amigam todo o tempo", enquanto Cardoso de Riacho de Oro atesta que os piolpi "gostam de beber brigam e depois no outro dia se amigam". Sobre os dapicochec, Victoriano expressa que - assim como as abelhas (dapic) — "são mais moleques, quando faz tempo ruim, mesmo que não se veja, encontram mel".

Tanto as problemáticas interações com os piolpi para Toba "mansos" como são os dapicochec, quanto os conflitos frequentes entre os Toba e os Pilagá se manifestam hoje em bairros periurbanos como Namqom. Ali, uma importante fonte de conflitos é a competição pelo domínio das ruas noturnas entre os jovens toba provenientes de Perín, reputados brigões, e os jovens provenientes da região de Bartolomé de las Casas, chamados depreciativamente de "orelhudos" por seus rivais e cuja destreza com a faca fez com que a zona onde se assentam fosse denominada Shangai, em referência aos mandarins orientais televisionados. Em Colonia Aborigen Chaco, até a instalação em fins dos anos 90 de uma delegacia na Central (conjunto de casas e comércio relativamente consolidado), os conflitos eram, em sua maioria, entre os do campo e os da Central ou, como dizem uns de outros, entre aqueles brutos, bêbados e brigões e os brancos "truchos" (falsos), orgulhosos.

Processos históricos diferenciados fazem com que, inclusive entre descendentes de uma mesma parcialidade, como os Toba de Riacho de Oro e de San Carlos, os primeiros enfatizem sua diferença em relação aos segundos, a quem consideram "gente do campo", sem vontade manifesta de progresso, ainda que humildes e hospitaleiros, qualidades estas tão apreciadas entre os Toba. 
No campo político-religioso do Evangelho ao qual aderiram com entusiasmo a partir dos anos 1940, os Toba estabelecem significativas diferenças entre aqueles que participam das igrejas comedidas e sóbrias, cuja pobreza dialoga com a humildade pregada, e aqueles que participam nas igrejas de celebrações festivas de rodas de jovens com grupos musicais, nas quais a abundância material confunde-se com o testemunho do cumprimento da promessa divina.

As diferenças entre os Toba surgem também em relação a uma subjetividade sempre em transformação ao longo do devir histórico. Características socialmente valorizadas, como o conhecimento, a sociabilidade, a força física, o valor e o bem-estar, são relativas à experiência de quem fala e à interpretação que faz das experiências daqueles a quem se refere. Para os Toba, historicamente confrontados com processos agudos de transformação, o lugar de quem fala em relação às gerações é de grande importância no momento de reconstituir o devir histórico. Fazendo um paralelo entre a relação de quem fala com o conjunto de pessoas que integra o seu discurso e a localização de Ego na estrutura de parentesco, podemos traçar algumas hipóteses sobre as diferenças e as semelhanças que se estabelecem entre "nós" (qo'omi), "os antigos" (toxoshic), e "os novos" (dalaxaic). ${ }^{3}$

A terminologia no interior da estrutura de parentesco corresponde à coletivização das gerações que costuma surgir quando os Toba põem em relação passado, presente e futuro. A construção das diferenças através das gerações corresponde às gerações definidas com termos genéricos. Em G0 um único termo (lqaỹa) é usado para nomear os cognatos de Ego, diretos e colaterais, pelo lado paterno e materno. Este termo é usado para designar os aliados de Ego da mesma geração na terminologia vocativa. Ainda que nesta geração existam quatro termos que designam os siblings mais velhos e mais novos de Ego segundo o sexo, as distinções de idade relativa não se refletem no sistema de atitudes.

Em G-1, ainda que se diferenciem os parentes diretos S, D (ỹale, ỹalec), os termos empregados para os parentes colaterais (ỹasoshe, ỹasoshec) se estendem a todos os filhos do germano SbS e inclusive a todos os filhos dos filhos reais ou classificatórios dos germanos do pai FSbChS. De forma semelhante, em $\mathrm{G}+1$, ainda que se diferenciem os parentes diretos M, F (ita'a, yate'e), os termos empregados para os parentes colaterais (ñitesoqo, ỹasoro) se estendem a todos os irmãos, reais ou classificatórios, do pai e da mãe, inclusive a todos os filhos reais ou classificatórios dos germanos do pai do pai FFSbS e a todas as filhas reais ou classificatórias dos germanos do pai do pai FFSbD.

Em G-2, um único termo é empregado (iual) para o masculino e o feminino, diretos e colaterais. Em G+2, embora a terminologia distinga os masculinos (ỹape) dos femininos (come), não se estabelece uma diferença 
entre os diretos e os colaterais. Todos os parentes ascendentes de $\mathrm{G}+3$ compartilham a denominação sexualmente distinguida (ỹape e come). Na ausência de uma relação direta, tais parentes são reconhecidos pelo termo genérico de "os anciãos" ou "os de antes" até um ponto relativo em que se convertem em "os antigos". Em G-3 produz-se uma relação semelhante: na relação direta, os parentes de Ego são iual. Quando esta relação não existe, estes são reconhecidos pela denominação genérica de "os novos".

Quadro n. 1 - A terminologia de parentesco toba, as gerações e o devir histórico

\begin{tabular}{|c|c|c|c|c|}
\hline $\mathrm{G}+2$ & \multicolumn{3}{|c|}{$\leftarrow$ у̃ape' у соте $\rightarrow$} & $\begin{array}{c}\text { Os avós, os velhos, os } \\
\text { antigos, os de antes }(\uparrow)\end{array}$ \\
\hline $\mathrm{G}+1$ & $\leftarrow$ ñitesoqo & ita'a, yate'e & ỹasoro $\rightarrow$ & \multirow{3}{*}{$\leftarrow$ Os de agora $\rightarrow$} \\
\hline G 0 & \multicolumn{3}{|c|}{$\leftarrow$ lqaỹa $\rightarrow$} & \\
\hline G-1 & $\leftarrow$ ỹasoshe & ỹalec, ỹale & ỹasoshec $\rightarrow$ & \\
\hline $\mathrm{G}-2$ & \multicolumn{3}{|c|}{$\leftarrow$ iual $\rightarrow$} & Os netos, os novos $(\downarrow)$ \\
\hline
\end{tabular}

Contando com a heterogeneidade e a multiplicidade como elementos característicos, esta subjetividade em devir põe em xeque a ideia de um Povo Originário unido por uma prática essencialista da identidade; o respeito irrestrito a um modelo "original" de organização social; a passividade diante dos mecanismos estatais de produção de alteridade; ou a adesão "estratégica" motivada pelos benefícios do indigenismo multicultural mais recente. Vejamos agora o devir histórico toba a partir de alguns aspectos de sua interação com os brancos.

\section{O Evangelho, a terra e a cidadania: três contextos de relação com os brancos}

Das análises sobre as relações com os brancos de diversos grupos indígenas da América do Sul, do Chaco, dos Andes e das Terras Baixas da região amazônica (Renard Casevitz 1988; Hugh Jones 1988; Harris 1995; Severi 2000; Fausto 2001; Gow 2001; Villar 2005), ressaltamos sinteticamente aquelas que retomaremos em nossa própria análise. As representações indígenas dos brancos são guiadas pelo eixo da experiência em suas relações de alteridade com os exo-grupos, por um lado, e com os seres não-humanos, por outro. Considerar os brancos como seres sobrenaturais não implica um sinal de submissão ou de dominação inerente: assim como os seres não-humanos, 
os brancos se caracterizam por sua ambiguidade. A forma pela qual os não-humanos e os humanos se distinguem em diferentes sociedades é extremamente variável, sendo particularmente incomum o grau de descontinuidade, uma característica da modernidade no Ocidente. É a analogia, e não a identidade ontológica, a base das formas distintivas da identificação dos brancos como seres poderosos.

Propomo-nos a analisar três dinâmicas de interação com os brancos a partir das quais os Toba edificaram alguns dos traços mais importantes de sua subjetividade contemporânea. A relação dos Toba com a terra, a cidadania e o Evangelho ${ }^{4}$ se produziu de maneira articulada e exerceu uma ruptura em seu devir histórico. Abordaremos em seguida as múltiplas leituras possíveis sobre os acontecimentos ligados à cidadania, a terra e ao Evangelho, com o fim de demonstrar que, entre os Toba, a relação com os brancos é parte fundamental no processo mesmo de constituição da subjetividade. Finalmente, analisaremos a noção de agência toba em relação às tensões entre diversos modos de representação do passado.

\section{Terra, Evangelho e cidadania: uma identidade em devir}

O acesso à cidadania, que grande parte dos Toba do centro-leste chaquenho situa na década de 1940 e vincula à emergência do peronismo no cenário nacional, lhes permitiu compartilhar com os brancos uma nova identidade, entendida como meio de acesso a um potencial, à riqueza ou, pelo menos, a um nível semelhante de bem-estar. Esse igualitarismo institucional adquiriu dimensões quase ontológicas para muitos Toba, que lembram da entrega/conquista do Documento Nacional de Identidade (DNI) quando chegaram aos seus domínios militares, funcionários que, encarregados de lhes entregarem tal documento, ordenavam homens e mulheres em fila. Ao serem interrogados sobre seu nome, a idade e a ocupação, os Toba respondiam com silêncios, ambiguidades ou nomes em toba. À medida que os militares impunham nomes, ocupações e datas de nascimento "verdadeiros", os Toba eram dotados de um nome, uma "atividade" e um ciclo vital, ajustados ao idioma, à cultura, ao tempo e à economia nacionais. Os Toba não se limitam a correlacionar este evento com a violência ou o exercício da hegemonia. Ao invés disso, a entrega do DNI costuma ser evocada como um ritual de entrega de nomes, de ocupações e de nascimentos em que as novas subjetividades em jogo prometiam acabar com o "sofrimento".

A propriedade da terra foi o segundo eixo sobre o qual se construiu a nova subjetividade indígena. O impulso governamental em direção ao 
índio produtivo havia se materializado já no início do século com a criação de reduções governamentais (Bartolomé de las Casas, Napalpí), missões religiosas de vocação agrícola (Misión Laishí, Misión Tacaaglé) e reservas (Teuco Bermejito). Fora dessas formas institucionalizadas, o principal mecanismo com que os Toba contaram para ter acesso à propriedade da terra foi a interação personalizada com os brancos. Os relatos dos Toba sobre a obtenção da terra enfatizam, por um lado, o protagonismo de caciques como Taygoyi', Moreno ou Pedro Martínez e de inumeráveis "caciquillos" (caciquezinhos) que viajavam até Buenos Aires para exigir a propriedade da terra. Por outro lado, as relações dos Toba com os criollos, que "eram bons, se davam bem com os Qom (com os Toba) e davam trabalho". Para extrair maiores rendimentos de sua força de trabalho, os colonos convidavam os Toba a se assentarem como seus empregados nas proximidades de suas fazendas. Assim, a condição dispersa e negociada da conquista da terra reabriu a porta para a liderança dos chefes das famílias extensas.

Ao permitir uma renovação individual e coletiva e a consolidação de um novo marco axiológico, o Evangelho é o terceiro eixo sobre o qual se forjaram os novos Qom. Desde a fundação de diferentes missões, nas décadas de 1930 e 1940, por parte de igrejas protestantes inglesas e norte-americanas, o evangelismo ensejou a produção de "pessoas novas". Marcada por um processo de individualização de testemunho da fé e do "amor de Cristo", a experiência evangélica centrou-se no "gozo" (ntonaxaq) do indivíduo, na proteção dos ataques xamânicos e na cura. O processo de constituição do crente é, em si mesmo, um testemunho vivo de histórias pessoais marcadas pelo sofrimento, a enfermidade, a rejeição, e por uma ruptura que permitia o surgimento de uma vida nova.

Assim como para muitas outras sociedades indígenas nas quais a evangelização constituiu uma "verdadeira mudança de ponto de vista" (Fausto 2005:405), entre os Toba a renovação coletiva foi similar àquela que se produziu na órbita individual. O Evangelho alentou uma renovação coletiva mediante o impulso para o processo de sedentarização estreitamente articulado à fundação das igrejas.

\section{Terra, cidadania e Evangelho: sua correlatividade}

A interação dos Toba com os brancos no que se refere a terra, à cidadania e ao Evangelho tem correlação com diversos elementos, dentre os quais destacamos: as novas lideranças, a continuidade entre suas práticas e discursos e a ruptura com o passado. Quanto às lideranças específicas, as 
evocações indígenas da cidadania identificam seu principal antecedente na exploração econômica em grande escala dos indígenas durante a primeira metade do século XX, especialmente nos engenhos de açúcar. Dessa experiência, os Toba ressaltam a liderança do "cacique geral" sobre uma massa de indígenas cuja homogeneidade relativa derivava de uma experiência de exploração laboral compartilhada. Na lembrança dos Toba de hoje em dia, o protagonismo do cacique geral na incorporação de contingentes de trabalhadores conjuga-se à imagem de um líder cujo poder provinha tanto de seu reconhecimento por parte de autoridades da sociedade nacional (produtores agrícolas, missionários, políticos), como de sua coragem e força física, sua infatigável defesa dos Qom, seu "falar grosso aos brancos" e seus poderes xamânicos (como sua capacidade de vislumbrar o futuro, intuir os perigos e comunicar-se com os pássaros).

A consolidação da liderança do cacique geral — protagonizada na região de Las Palmas pelo cacique Moreno, e na zona de Pampa del Índio, primeiro, por Taygoyi' e, posteriormente por Pedro Martínez - teve seu apogeu em meados do século XX com o surgimento do peronismo no cenário nacional (1946-1955). Inúmeros relatos, como o do enfermeiro e cantor evangélico Teófilo de Pampa del Indio que citamos a seguir, evocam caciques gerais que viajavam até Buenos Aires para dialogar com autoridades políticas. Esses relatos descrevem um jogo de perspectivas em que os Toba explicam o seu carecer de direitos, vendo-se como ontologicamente diferentes na ótica dos brancos. Assim, foi através da viagem que caciques como Martínez derrogaram a distância — geográfica e subjetiva — até então vigente entre o Presidente - arquétipo dos brancos - e os Toba:

Foram para Buenos Aires 17 caciquillos com Pedro Martínez. Quando os índios se apresentaram a Perón, ele viu que não eram gente estranha. Não têm três orelhas ou seis olhos, são iguais a nós, eles têm direito [...] disse Martínez: "Nós queremos documento e terra". E Perón disse: "É difícil. O único que vou lhe dar é dinheiro", e lhe entregaram uma caixa. O linguarudo disse: "Não, o dinheiro acaba. Martínez quer terra". Tiraram um mapa do Chaco com todos os povoados. "Ali, esse [lugar] está livre". Era Teuco Bermejito [região situada entre os rios Teuco e Bermejito].

A viagem a Buenos Aires de Martínez foi também inaugural em um sentido religioso. Além de entregar os títulos de terra, Perón autorizou os Toba a "terem" suas igrejas através do cacique Martínez, a quem numerosos Toba de Pampa del Índio, como Teófilo, evocam percorrendo a região, conquistando a terra e fundando igrejas: "Chegou a ordem, saiu nos jornais 
e os criollos leram: 'vão dar a terra aos índios'. Martínez entrou em Las Palmas, Margarita Belén, San Martín, Lote 60 e assim ia formando gente e ia obtendo toda essa terra".

A gestão local das igrejas impulsionou a sedentarização ao permitir/ requerer uma nova experiência de organização. Tais experiências, geradas pela agenda participativa das igrejas através de cargos como porteiros, pastores ou secretários, inscreveram-se nos panoramas políticos locais. Estas novas lideranças articularam-se às já existentes, representadas por chefes de famílias extensas, xamãs e jovens cuja ascendência derivava de seu conhecimento do castelhano e de sua destreza para atuar em um contexto político no qual circulam papéis escritos.

Cidadania, terra e religiosidade ficaram ligadas a partir da renovação, seus preceitos de "amansamento" e o impulso à sedentarização. "No tempo de Perón" — recorda um ancião toba, pastor evangélico de Pampa del Índio — "recebemos a terra; todos nós somos pastores; quando nos encontramos com o missionário Lagar, ele nos fez pastores". Tal como afirma o líder Gómez de Pampa del Indio, os primeiros povoadores chegaram atraídos pela notícia de que "havia terra e culto": "Diziam que sobrava terra. Alguns vêm, conhecem e depois vão e buscam sua gente. Quando entraram no Evangelho, começaram a trabalhar a terra, os velhos estavam se educando".

Habitantes de Pampa del Indio, Misión Laishí, Riacho de Oro e San Carlos evocam do "começo do Evangelho" os extensos percursos que os Toba empreendiam a pé até Resistência, onde se encontrava desde 1941 o pastor Lagar "curando e pregando o Evangelho". No caminho de volta, o Evangelho contribuiu para a sedentarização, ao incentivar, como refere o ancião Capra, os novos crentes a "procurarem seu lugar", cultivarem a terra e se assentarem: "A meu pai Juan Luis foi revelado em 1944 para viver aqui. O evangelista Lagar lhe deu esse pensamento. Não tinham um lugar onde se assentar. Lagar lhe disse que percorresse esta parte, que procurasse um bom lugar para produzir e que procurasse um marco de fronteira e anotasse o número. Veio sozinho mariscando [caçando]".

Como relata Capra, os missionários frequentemente convidavam os recém-nomeados pastores a construir templos em suas comunidades: “Lagar era um embaixador e tinha todos os poderes e solicitou às autoridades que abrissem caminho à tribo de Juan Luis. Quando chegaram aqui era deserto, não havia ninguém. Tinham o atestado de Lagar e ele se fez fiador. Quando chegou, deixou sua tribo e depois foi a Villafañe; [nessa cidade] aceitam e carimbam os papéis. Depois [Juan Luis] tornou-se o primeiro pastor".

Articulados, o Evangelho, a terra e a cidadania tenderam a exercer uma ruptura com o passado. A transformação dos Toba caçadores em agricultores 
inscreveu-se na lembrança dos acampamentos [tolderías] como espaço da marginalização, da mobilidade como fonte de pobreza e na promessa de bem-estar que oferecia o Evangelho aliado a terra. Bernardo de Pampa del Indio afirma: "a Bíblia em Provérbios diz que aquele que lavra sua terra e aquele que sua a camisa terá pão, enquanto aquele que segue vagando conseguirá pobreza".

\section{As múltiplas leituras possíveis sobre os acontecimentos}

Os Toba do centro-leste chaquenho habitam atualmente comunidades dispersas, de tamanho reduzido e cercadas por propriedades privadas. Ainda que os assentamentos compartilhem de um mesmo correlato de marginalização espacial, de uma estabilidade definitivamente adquirida e do acesso a uma nova condição cidadã, sua constituição esteve ligada às especificidades tanto da localização relativa à colonização produtiva, quanto da frequência e da intensidade da subordinação de seus habitantes às atividades econômicas capitalistas.

Atualmente, em algumas regiões associadas aos "antigos" e à mata, exalta-se um passado relativamente idealizado de abundância, vigor físico, solidariedade e autonomia. Em outras, a sedentarização é reivindicada como conquista da integração à sociedade nacional, inscrita em uma sucessão coerente de eventos entre os quais se inclui a participação em atividades produtivas, na construção das vias férreas, na preparação dos rios para torná-los navegáveis ou em guerras nacionalistas, como a da Tríplice Aliança. Estas leituras antagônicas, assim como as múltiplas outras possíveis que podemos situar entre elas, não são excludentes, e as diversas origens de seus protagonistas produzem diferenças mais de intensidade do que de sentido.

Os "novos" Qom de hoje em dia, como se reconhecem por oposição aos "antigos", tenderam a apagar, ao menos parcialmente, as diferenças entre as antigas parcialidades e efetuaram, de forma heterogênea, uma ruptura mais ansiada que efetiva com um passado frequentemente evocado como um tempo de ignorância, selvageria e pobreza. Não obstante, sempre realizadas a partir da experiência de quem fala, as leituras do passado expressam as diferenças geradas pelos processos históricos. Assim, os acontecimentos são lidos a partir de múltiplas perspectivas ligadas a diversos repertórios interpretativos. As próprias experiências individuais ou coletivas em determinado momento e lugar estabelecem perspectivas de interpretação das experiências tanto próprias como dos "antigos" e dos "novos". 
Os "antigos", que em muitos casos são corajosos, sãos e livres, são também vistos como ignorantes, selvagens e tolos. Os "novos", que são exaltados por seu conhecimento no uso de computadores, são denegridos por seu desconhecimento de como manter um lar, das normas sociais e das regras de parentesco. Os "novos" e os "antigos" podem ser simultaneamente ignorantes ou sábios - quando se fala das "coisas dos brancos" ou do passado - e livres ou escravos quando se fala do Evangelho. Enquanto os "antigos" são às vezes ariscos, às vezes selvagens e às vezes rebeldes - na maioria das vezes tudo isto ao mesmo tempo — os "novos" podem ser simultaneamente, ou não, submissos, covardes, débeis, civilizados, astutos ou hábeis. Como sinalizou Villar a partir de seu trabalho entre os Chané (2007), a diversidade de perspectivas depende por sua vez do "registro moralista, narrativo ou pragmático que se enfatize", sem que sua lógica contraponha nitidamente a unidade e a multiplicidade" (2007:396).

A interpretação das experiências desde pontos de vista diversos dialoga com um devir histórico cuja heterogeneidade reside nas diferenças interpretativas de grupos sociais sincrônica e diacronicamente diferentes. Não obstante, se no nível sincrônico a diversidade de perspectivas encontra seus limites na multiplicidade de famílias, "comunidades" ou grupos em interação, no nível diacrônico a diversidade de perspectivas encontra uma dupla dificuldade. Por um lado, ao seguirmos as gerações ascendentes e remontarmos ao passado, encontramos a existência de pessoas cujas experiências prévias à colonização não se produzem em relação ao Estado nem aos brancos. Por outro lado, carecemos de fontes históricas que nos permitam acessar a experiência de tais pessoas e suas perspectivas. Somente nos resta acessá-las por relatos "míticos". Gow já nos oferecia uma saída para este impasse ao afirmar, referindo-se aos Piro: "A história indígena é um eixo em cujos extremos se encontram as experiências pessoais dos indígenas atuais e os relatos míticos. Todo o resto se situa em algum lugar entre esses dois extremos" (2001:288, todas as traduções são minhas). Antes de retomarmos este ponto, vejamos algumas das bases que sustentam a constituição de uma subjetividade coletiva em face das relações com os brancos, por princípio assimétricas.

\section{A assimetria, suas múltiplas leituras possíveis e a agência toba}

Apesar de sua grande heterogeneidade, as relações dos Toba com os brancos no que diz respeito a terra, ao Evangelho e à cidadania compartilham várias características. Principalmente a de promover, pela coação e/ou pela 
força, a consolidação entre os Toba de formas de identidade coletiva que permitem, ou não, que eles - já agora convertidos em cidadãos, crentes ou agricultores - tenham acesso a benefícios materiais. O vínculo entre a dimensão relacional da identidade e a resolução das condições de existência revela outra característica comum: a de constituir modelos relacionais assimétricos nos quais, por enquanto, reconhecemos que os lugares inferiores são reservados aos Toba e os superiores, aos brancos (missionários, políticos, capatazes, proprietários de estabelecimentos).

As relações dos Toba com os brancos quanto a terra, ao Evangelho e à cidadania estão, além disso, ligadas a objetos, como armas, bandeiras, documentos ou sementes, que condensam as características de tais relações. O papel dos objetos nas relações com os brancos foi abordado, entre outros, por Fausto (2001), Bonilla (2005) e Kelly (2005). Em consonância com Gow, nossa análise indica que as relações que nos ocupam entre brancos e índios excedem a hegemonia e a resistência e se caracterizam por serem "relações 'objetalmente' mediadas" (2001:306), nas quais "o desejo dos objetos" está ligado ao "desejo das relações sociais que tais objetos, para além de sua utilidade, corporificam"(ibid.). Falar da diferença com os brancos implica, entre os Toba, falar de objetos indo e vindo de índios para brancos ou de brancos para índios. Como indica Timoteo de Namqom, em tais movimentos, a submissão e a reivindicação estão longe de permanecer isoladas e muito menos opostas:

Meu avô lembra de Pedro, um guerreiro. Um dos nossos, Weraik. Esse homem é como um pai dos aborígenes; não sei em que ano era. Quando ele estava no meio do campo, fincou uma bandeira. Então ele tinha essa bandeira. E quando os brancos souberam que um aborígene tinha uma bandeira, todos vieram aqui, não conheciam, mas vieram: "onde está esse homem?". Queria tirar a bandeira. Então, quando tirou a bandeira, diz que uns alçaram as mãos assim, e todo o exército alçou as mãos e abraçou o homem [Weraik] e lhe pediu que lhe entregasse a bandeira, e ele entregou a bandeira. E o levaram até nosso patrício e o restante das pessoas, mas não sei onde o levaram. Foi a primeira bandeira, não se sabe quem lhe deu. Mas ele a tinha, essa bandeira. Os brancos não tinham bandeira. Num 20 de junho entregou aos brancos. "A bandeira argentina não é deles", disse ele, "é nossa, mas nos tiraram, então, esse poder fica com eles".

Entre os Toba, como em outras sociedades indígenas, os objetos escolhidos por brancos e índios estabelecem diferenças econômicas, estilos de vida, valores, definem cada grupo socialmente e as relações entre eles. As relações com os brancos que se produzem através do Evangelho, da terra e da cidadania contam com um conjunto de objetos circulando entre brancos 
e índios. Entre estes, têm uma função importante "os papéis", como os títulos de terra, o Documento Nacional de Identidade e o Arquivo de Culto. ${ }^{5}$ A partir de seu trabalho entre os Toba do Oeste, Gordillo afirma que os documentos estatais como os que nos ocupam foram desde seu início "produtos ad hoc que individualizaram significativamente tanto o autor quanto o beneficiário" (2006:166). Definindo-os como "tecnologias de poder" (2006:172) e postulando o vínculo de tais objetos com "a exploração, a pobreza ou a marginalização política" (2006:164), Gordillo descreveu também a aura de "fetichismo" que envolve os documentos estatais de identidade.

O encontro do cacique Pedro Martínez com Perón em Buenos Aires nos permite analisar desde a importância dos objetos em referência até a nova subjetividade em construção. Teófilo de Pampa del Indio conta que em seu encontro com o cacique Martínez, em Buenos Aires, Perón lhe disse: "Vá até a gobernación' [refere-se ao Território Nacional do Chaco]. E Martínez respondeu: 'Eu quero um sinal para que me respeitem'. E Perón disse: 'Darlhe-emos um uniforme militar, espada, pistola, botina e chapéu. Com esta arma e este uniforme pode armar seu grupo'". Para reforçar o poder do cargo e da farda, o governo entregou ao cacique geral uma quantidade importante de fotografias, que ele distribuiu à população. Como afirma Teófilo, o cacique Martínez, "junto com os títulos da terra, recebera de Perón um uniforme de Major. Quando regressou, trouxe um montão de fotos e as repartiu".

Parafraseando Hugh Jones (1988:146), podemos afirmar que, "rejeitando e elegendo", os Toba inscrevem a diferença com os brancos na esfera da responsabilidade. Para os Toba, a agência se exerce tanto de maneira ascendente como descendente em um esquema relacional assimétrico entre brancos e índios, de cuja possibilidade de inversão dão conta os títulos de terra, o DNI e o Arquivo de Culto.

A relação dos Toba com os brancos caracteriza-se também por sua relatividade e por suas múltiplas leituras possíveis. Retenhamos aquela a partir da qual a terra, a cidadania e o Evangelho podem ser interpretados como uma conquista e como contextos relacionais nos quais se procede ao amansamento dos brancos. Diante de brancos que, salvo exceções, são poderosos, impiedosos, elusivos, inescrupulosos e irremediavelmente ariscos, tal aproximação centrou-se, para os Toba, na transformação da própria subjetividade como condição de estabelecimento do contexto relacional necessário para reduzir a distância social e inverter a assimetria.

A releitura do passado e do devir histórico não impede que as interações com os brancos sejam vistas pelos Toba como contextos relacionais nos quais as decisões e as atitudes dos "antigos" firmaram as bases da constituição dos novos Qom. Para os Toba de hoje em dia, os antigos e sua ignorância 
costumam ser evocados como os culpados de os "doadores de benefícios" terem sempre preferido ajudar os outros. A origem da diferença com os brancos e seu principal correlato - a desigualdade étnica no acesso à riqueza - é um tema privilegiado para os atuais Qom que, com mais ironia do que tristeza, costumam zombar dos velhos; estes, além de se equivocarem permanentemente, "cozinhavam a melancia e não sabiam preparar os alimentos dos brancos".

Dos relatos históricos, os Toba costumam enfatizar os sucessivos erros dos antigos ao não tomarem as decisões adequadas. Para referir apenas um exemplo, os Toba da zona de influência de Misión Laishí evocam o erro dos antigos que, ao trazerem o sacerdote e ao lhe informarem que ali havia "terra boa", provocaram a marginalização que atualmente sofrem os Toba das colônias periféricas da Missão, como El Naranjito ou Laguna Gobernador. A acusação aos antigos é situacional e não permanente. A partir de sua experiência atual de injustiça, pobreza e discriminação, os Qom de agora atribuem uma capacidade de ação aos antigos, mesmo sabendo o contexto histórico de submissão e violência que enfrentaram.

Finalmente, às múltiplas perspectivas através das quais se interpreta o devir histórico somaram-se outras novas, edificadas a partir do surgimento do indigenismo "reivindicativo", que se diferencia de outras formas de indigenismo estatal edificadas por meio do paternalismo ou da assimilação. Ainda que a análise deste novo campo de relação não seja nosso objetivo, sua importância atual merece um breve comentário. O surgimento do indigenismo reivindicativo acompanhou o interesse na agência indígena. Entretanto, como tentamos demonstrar, é mister escapar da ilusão da resistência permanente que convida à reescritura do devir histórico dos Toba a partir da perspectiva contemporânea. Como muitos trabalhos demonstraram (Harris 1995; Renard-Casevitz 1988; Hugh Jones 1988; Severi 2000; Gow 2001; Fausto 2001; Kelly 2005), as motivações em determinados contextos dificilmente podem ser entendidas fora da ambiguidade, da ambivalência e da contradição que caracterizaram a relação com os brancos. Da agência dos Toba em suas relações com os brancos, que protegem tanto como dominam, dificilmente poderemos dar conta sem rompermos a oposição entre diferentes formas de narrar o devir histórico, de empreender a ação política e de constituir as lideranças.

\section{Uma subjetividade de escolhas permanentes}

Entre os Toba, numerosos mitos referem a importância das escolhas no processo de diferenciação de índios e brancos de seres que compartilhavam 
uma mesma condição, um mesmo idioma e uma mesma natureza. Apoiados na literatura chaquenha, vejamos sinteticamente como os índios se tornaram índios: por terem se apresentado a eles em uma falsa aparência (tamanho reduzido) ou por lhes provocar temor, os Qom rejeitaram as oferendas dos seres não-humanos de "animais úteis" e de armas (Karsten 1932:207). Os Qom foram também incapazes de demonstrar destreza para pôr o freio e as rédeas nos cavalos (Palavecino 1964:286). Por último, os Qom desobedeceram e não quiseram escutar os seres não-humanos (Métraux 1946:94).

Junto com más escolhas, tolices ou desobediências, os Qom permaneceram na condição de índio aparentando ter "somente" arcos e flechas (Karsten 1932:207), não receber nada, não ter nada e estar coberto com tapa-sexo (Métraux 1946:94). Tornar-se branco, por sua parte, implicou um novo idioma (Palavecino 1964:286), possuir objetos (Karsten 1932:207), estar bem vestido e ter, além de "verdadeiros" objetos, chimarrão, comida e trabalho (Métraux 1946:94).

Os elementos descritos da relação dos Toba com os brancos através do Evangelho, da terra e da cidadania encontram-se nos relatos sobre o surgimento dos brancos, dos Qom e da diferença entre eles. "A grande chuva" (Palavecino 1964:285), que narra a chegada ao acampamento de um cachorrinho sarnento no meio de uma chuva torrencial, dá conta da assimetria, do vínculo entre identidade e condições de existência, dos objetos que corporificam essas relações e da agência indígena. Ainda assim, o vínculo já citado entre a reprimenda ao protagonista pela transgressão de atitudes socialmente valorizadas como a compaixão e a hospitalidade e "o erro" dos antigos em suas escolhas é evidente. Também o fato de que a relação dos Qom com os brancos e com os seres não-humanos poderosos transita no mesmo canal de más escolhas, recusas de bens, formas inadequadas de hospitalidade e posições de poder correlativas e cambiantes (com seres tão irrelevantes em sua aparência como poderosos em sua verdadeira natureza, por exemplo). Segundo o relato, um homem e sua mulher oferecem abrigo ao animal que, durante a noite, se transforma em homem e diz ao velho: "Você é meu filho porque me salvou. Eu vou te dar semente, animais, tudo, e aos demais nada porque me expulsaram. Eu vou te dar outro idioma também" (Palavecino 1964:285).

As escolhas como linha argumentativa nas explicações sobre a origem da diferença com os brancos são frequentemente realizadas ainda nos dias de hoje. Em 2004, Israel, um líder político de Namqom, fazia referência a um ser não-humano que "antes dos brancos chegarem, descia e colocava quatro pauzinhos na terra. No dia seguinte havia uma casa completa". Em seguida, continua Israel, "nosso pai oferecia fazer um curral e no outro dia 
apareciam as vacas. Mas as pessoas rejeitavam". Segundo Israel, o ser nãohumano "ficou triste e abandonou o povo indígena e entregou toda a riqueza aos brancos. Se eles aceitassem, estariam longe de ser subjugados".

Descrevendo a origem do poder de Taygoyi", em 2002, Milciades, um velho líder de Pampa del Indio, vinculava as tensões geradas pela conquista e a colonização a uma subjetividade de escolhas na qual os objetos corporificavam formas de ação política e sistemas de atitudes em relação aos brancos: "Na mata havia dois homens com um poder natural. Um mostrava [a Taygoyi"] uma arma e o outro umas sementes e lhe perguntavam: 'Do que você gosta mais?' Ele pegou a arma e disse: 'Com esta vou me arranjar'".

As relações dos Toba com os brancos se situam nas tensões entre mito e história que, como afirmou Hugh Jones (1988) em seu trabalho entre os Barasana e os Wâribi, coexistem como modos complementares de representação do passado. As experiências dos atuais Toba de relação com os brancos são vinculadas a experiências similares de seus pais e seus avós. Os Toba vinculam também as experiências ("históricas") de relação de seus pais e seus avós com os brancos com a relação dos "antigos" com outras formas de alteridade. As formas como os brancos, sua natureza e sua cultura foram interpretados dependem de categorias previamente existentes de alteridade (Harris 1995). As experiências pessoais dos antigos se produzem em contextos nos quais as relações de alteridade se estabeleciam exclusivamente com os exo-grupos e com os seres não-humanos. ${ }^{6}$

Vejamos uma última característica da relação assimétrica entre os seres não-humanos poderosos e aqueles que se fizeram diferentes por suas escolhas. "Você é meu filho porque me salvou" (Palavecino 1964:285), diz o cachorro sarnento ao seu protetor, já na sua condição de ser não-humano poderoso. O processo de separação entre brancos e índios se materializa com seres não-humanos tratando como filhos-protegidos aqueles que se diferenciaram por sua habilidade ou suas boas escolhas. A entrega de sementes, animais e um novo idioma se produz através de um vínculo de parentesco. A diferenciação dos Toba e dos brancos é a história de uma separação que se expressa através de relações de parentesco que se fazem e se desfazem.

A relação com os seres não-humanos compartilha com a relação com os brancos as mesmas propriedades da ambiguidade entre a proteção e o domínio. Vincular a relação dos Toba com os brancos e com os seres não-humanos está longe de responder à reprodução permanente de uma estrutura de relação idêntica no tempo. A etnografia demonstra como os mesmos Toba contradizem a estabilidade dos mapas cosmológicos e a ideia de um universo mítico estático e a-histórico, nos quais a adscrição espacial de determinados seres não-humanos é aceita e assumida como algo dado e não como parte de 
um processo dinâmico. A figura dos pais-donos das espécies (como os pais donos das espécies animais e vegetais - pai: -lta" $a$ e mãe: late"e-) demonstra a articulação de uma situação de assimetria com relação à experiência histórica dos Toba (Salamanca 2006). A emergência de novas denominações para os pais/mães das espécies como a de "dono" ou "rei" alude à interação dos indígenas com a sociedade nacional, às suas novas formas de interação com um território colonizado, segmentado e privatizado e às mudanças acontecidas como consequência destas novas relações históricas. A utilização indistinta das denominações de pai, dono ou rei expressa também a convivência de novos contextos relacionais e de novas formas de narrar e descrever a assimetria. Estas transformações dão conta, por sua vez, da passagem de um espaço cuidado e governado por pais a um espaço dominado por donos que administram bens. As transformações da relação de subordinação pai/filho na relação dono/propriedade dá conta da instauração de uma relação de dominação produzida pela incorporação de uma ideia de propriedade sobre segmentos territoriais e sobre o alimento que neles se encontra, ao qual os Toba têm acesso cada vez com maior dificuldade. Assim como os brancos com os quais se relacionam os Toba, os seres não-humanos - e, por conseguinte, a própria relação em si — transformou-se historicamente.

Nosso argumento requer uma última seção, na qual analisaremos a experiência de um grupo de famílias que, instalando-se em uma zona periurbana, parece ter se proposto a uma aproximação aos brancos sem reservas.

\section{Sobre o surgimento do bairro Namqom}

Situado 11 quilômetros a oeste da cidade de Formosa, Namqom se consolidou a partir dos anos sessenta. Ainda que situados fora do perímetro urbano, os Toba de Namqom se aproximaram dos brancos do centro procurando sua inserção na burocracia governamental, obtendo trabalhos informais e fabricando artesanato. Por sua localização sobre o principal eixo rodoviário da província, a Estrada 81, Namqom constituiu-se também como um importante nó dentro da trama de comunidades, verdadeira geografia indígena que, ainda que fragmentada, é tecida pela mobilidade permanente de seus habitantes. Namqom converteu-se assim em porta de entrada e saída de Formosa, epicentro burocrático estadual, especialmente a partir dos anos 80 .

Os velhos habitantes de Namqom costumam citar, entre as razões para seu deslocamento, a exploração sofrida nas fazendas privadas, a dificuldade de assentar-se no campo sem ferramentas e dinheiro e as falsas promessas de 
terra por parte das autoridades. Muitos deles referem também situações nas quais os acontecimentos se inscrevem no espaço, constituindo um território marcado pela experiência da desterritorialização.

O surgimento de Namqom se inscreve no contexto de meados do século caracterizado por um grande conflito, que tem entre sua causas: uma imigração europeia ainda no auge, os ritmos de apogeu e declínio da exploração agrícola e a voracidade com que proprietários privados buscavam se apossar de grandes extensões de terra ainda fiscais. A obtenção precária da terra por parte dos Toba enfrentou ainda a ação institucional que favorecia o monopólio e a exploração, a anarquia jurídica, a injustiça do aparato judicial e os procedimentos burocráticos cujo epicentro foram sempre as grandes cidades. Ao carecer de recursos econômicos para delimitá-las, os Toba enfrentaram a dificuldade de defender as terras como próprias.

Enfatizando esta leitura dos acontecimentos, em sua análise sobre os assentamentos toba de Rosario, Bigot, Rodríguez e Vázquez (1992) encontraram no "sincretismo de pautas culturais da nova região de assentamento" (ibid.:82), uma "estratégia de sobrevivência" e postularam também a forte ambivalência étnica entre o orgulho e a vergonha (ibid.). Esse trabalho propõe o conceito de "campos de interação socio-étnicos" como "zonas de conflitos entre grupos étnicos diferenciados onde a imposição de um grupo étnico sobre outro estabelece uma situação de domínio-sujeição" (ibid.). Referindo-se aos Toba em La Plata, Tamagno (1992) reconhece um conjunto de identidades (étnica, social e religiosa) como formas de articulação com a sociedade nacional e afirma que os conflitos inerentes às dinâmicas de "atualização de [tais] identificações" são a "expressão da forma pela qual (...) se manifestam os interesses dos diferentes setores que conformam nossa sociedade" (ibid.:115116). Definindo o processo de constituição das identidades indígenas enquanto "processos de endogênese", em seu estudo entre os Toba de Rosário, Arias (2005:1) afirma: "Os índios urbanos consideram importante recuperar suas tradições culturais, exibir sua identidade e servir-se dela como instrumento de unidade e mobilização política e econômica".

Ao inscrever a chegada dos Toba a Namqom em um devir histórico mais amplo, complementaremos estes aportes elaborados prioritariamente a partir das relações de dominação que os Toba enfrentam atualmente em contextos urbanos. Demonstraremos que, à violência da sociedade nacional, os Toba de Namqom opuseram, em meados do século XX, uma nova subjetividade apoiada na terra, na cidadania e no Evangelho. Tal propósito e o surgimento de uma geografia percebida sob o esquema de uma riqueza concêntrica em torno das cidades deram lugar à instalação das famílias na periferia de Formosa, onde a "igualdade" com os brancos poderia finalmente se tornar efetiva. 


\section{A subjetividade como opção}

No devir histórico toba, um dos contextos nos quais a subjetividade foi debatida com níveis similares de complexidade aos presentes na constituição dos novos Qom é aquele no qual se efetuou a diferenciação entre humanos e animais. Nas histórias dos "antigos" são abundantes as referências a seres reiterando a importância das escolhas na definição correlativa da subjetividade. A possibilidade de vir a ser outro se vincula com escolhas próprias, dando conta de um conjunto específico de posições relacionais e de uma concepção da pessoa em devir.

Um relato mítico no qual se descreve a definição das atitudes dos seres humanos e dos animais apresenta alguns elementos de continuidade com os relatos que recompilamos sobre o surgimento de Namqom. Recorrendo a um relato mítico não estamos postulando sua função arquetípica em um contexto no qual nem seus protagonistas nem o mundo que descrevem parecem ter pertinência ou validade. Se a importância da dimensão histórica do mito excede o domínio da crença (Gow 2001:288), o mito contribui para desvelar a continuidade histórica de um conjunto de posições relacionais em contextos de relação assimétrica nos quais a opção pessoal é central no delineamento coletivo da subjetividade.

Neda'mik é um ser não-humano presente em um relato recompilado por Métraux (1946) entre os Toba-pilagá, também pertencente ao universo cultural e linguístico dos Guaicuru. Esse relato inscreve-se em um contexto caracterizado pelo recente aparecimento dos seres humanos na terra e pela ausência de diferenças entre humanos e animais. ${ }^{7}$ Neda'mik estabelece as relações entre animais e humanos, a quem transmite indicações sobre como transformar o espaço, quais hábitos alimentares adotar, como se comportar e como se relacionar com os demais seres.

Em outros trabalhos (Salamanca 2006), descrevemos a capacidade de escolha dos seres - animais, humanos e não-humanos - de um tipo específico de subjetividade, corpo e comportamento, assim como a importância da vontade individual em tal escolha. A capacidade de escolha dá conta da participação ativa dos seres no processo de se tornarem sujeitos e de sua capacidade de influir no estabelecimento de regimes corporais, comportamentos e atitudes e na adscrição a um espaço determinado. Esta agência baseia-se mas sem se restringir a ela — na inscrição do poder no sujeito, já que é ele quem decide, em face de uma série de alternativas possíveis, seu lugar e condição. Os múltiplos processos de diferenciação da subjetividade estão ligados a um conjunto dinâmico de intensidades relacionais entre diferentes seres, localizados, por sua vez, em uma sensível rede de posições correlativas: 
Depois de ter convertido quatro humanos em lontras e crocodilos, Neda'mik lhes disse: "Entrem todos na água!"; "Crocodilos: Deixem sua cabeça fora d'água! Vocês, as lontras, submerjam. Se vier o jaguar, escondam-se debaixo d'água. Crocodilo, se o jaguar quiser te pegar, arrasta-o para debaixo d'água. Lá você poderá comê-lo". Uma vez Neda'mik tendo convidado os jaguares a pegarem seu alimento na lagoa, um deles tentou se aproximar e, enquanto a lontra fugia, como lhe fora ensinado, o crocodilo permaneceu imóvel. Quando o tigre submergiu, o crocodilo apanhou-o e devorou-o. Surpreendidos pela hostilidade do crocodilo, os tigres perguntaram a Neda'mik: "o que faremos agora?", e Neda'mik respondeu: "se forem valentes e conseguirem suas presas seguirão sendo jaguares, do contrário terei que mudar sua forma" (Métraux 1946:78-83).

Já longe da lembrança de Neda'mik e demonstrando que não é o mito em si mesmo o evocado, mas as relações das quais ele dá conta, a abertura dos Toba - representada pela opção de se aproximar da cidade - requereu debater novamente as fronteiras da subjetividade. Ao chegar às proximidades de Formosa, as famílias instalaram-se debaixo de uma ponte sobre um riacho a $5 \mathrm{~km}$ da cidade, na atual Estrada 81. A assimetria desfavorável que as primeiras famílias encontraram na sua interação com os representantes do governo se viu modificada pela presença de Deus, ser não-humano cujo poder — ainda que superior ao dos governantes - é correlativo à fé dos Toba. Tal fé é vista por estes últimos como a capacidade individual e coletiva para inscrever seu devir histórico no marco de significação de uma subjetividade renovada. Neste marco, a capacidade de ação — através da fé — depende da própria capacidade de transformação - em verdadeiros crentes. Assim, Cirilo, um dos primeiros habitantes a recordar as conversas com as autoridades descreve a sucessão de ações que permitiram às primeiras famílias conquistarem o lugar que desejavam: "um dia fizemos reunião e elegemos um presidente e um secretário. Fizemos uma nota ao governo. Pedimos primeiro a Deus, que é o dono da terra, que toque o coração desse governo. Por meio dele vamos conseguir um pedaço de terra. E então conseguimos o que pedimos com muita fé". Namqom condensa a conquista da cidade por parte dos Toba através de uma série de ações cuja causalidade é transferida dos Qom para Deus, de Deus para o "coração dos governantes" — sendo estes, segundo a perspectiva dos Toba, os depositários de sua vontade - e dos governantes para os Qom. ${ }^{8}$ Vejamos então, a partir desta perspectiva, como Namqom representou uma conquista que permitiu aos Toba obterem um lugar adequado à sua nova subjetividade.

Segundo os primeiros habitantes, inicialmente o governo ofereceu assentálos às margens de um rio, argumentando que ali não sofreriam fome graças à pesca. Em seguida, ofereceu-lhes um terreno onde poderiam cultivar e gozar 
as riquezas da mata. Para além das diferenças entre as versões, os entrevistados coincidem em afirmar que tais oferecimentos foram unanimemente rejeitados. Os desencantos contemporâneos dos Toba urbanos não nos devem ocultar o consenso que existia acerca do tipo de subjetividade à qual os Toba queriam aceder, naquele tempo. Cirilo, um dos primeiros habitantes, afirma a este respeito:

Primeiro quiseram nos dar [um terreno] atrás de Formosa, na lagoa Sian. Os militares dizem: "Aqui é perfeito, podem ficar bem porque fazem artesanatos e à tarde podem pescar, não vão passar fome". E quando um aborígene lhe dizia: "E se vem a enchente?", ele respondia: "Não, não há problema, vamos lhes dar canoas". Mas os Tobas rejeitaram: "Não, vamos procurar outro lugar". Então o encarregado diz: "Bom, vamos outra vez ao ministro para ver o que diz". No dia seguinte, ele veio e disse: "Há que decidir de uma vez por todas, assim vão conseguir um lugar só. Temos um lote ótimo para trabalhar a terra. Lá há mata, podem fazer carvão também". Mas as pessoas não gostam porque, como trabalhavam no artesanato, ficava muito longe para vender. E no terceiro dia o encarregado diz: "Há um lote (...) precisam ir 10 quilômetros para o lado de Clorinda". Viemos, nos deu o mapa. E era ótimo.

Como qualquer evento histórico, a gênese de Namqom é um projeto inacabado. Às diferenças que sustentam as múltiplas perspectivas de interpretação dos acontecimentos somaram-se as tensões provocadas por um novo contexto político que se consolidaria com a sanção das leis indigenistas. A partir desse contexto, se para alguns habitantes a capacidade organizadora das primeiras famílias deve ser um exemplo, para outros é o balanço "positivo" da relação com o governo que deve ser destacado ao constituir um antecedente "positivo" do paternalismo do Estado e dos partidos políticos.

Para aqueles chefes de famílias extensas com estreitas relações com partidos políticos e agências estatais, a criação do bairro é um testemunho do favor do branco como uma forma de acesso a terra e à cidadania. As palavras do pastor Mendoza e de outros líderes do bairro articulados aos partidos políticos enfatizam o papel dos brancos na "civilização" dos Toba: "Em 67 estávamos cegos. Não conhecíamos a cultura dos irmãos brancos. Quando um branco nos quer cumprimentar, não podemos, porque não sabemos falar. Não é medo. O regimento nos ensinou a falar, ensinou-me como devo administrar minha família. Tudo me ensinou".

Líderes indigenistas como Timoteo afirmam, ao contrário, que depois de as famílias reunidas enviarem uma nota ao governo, um dos líderes, Lucio Rodríguez, adquiriu grande protagonismo ao acertar na escolha do lugar onde ficaria o bairro, prevendo a existência de água "boa" (não-salgada, apta para o consumo) e a futura extensão da cidade. Da mesma forma, 
Rodríguez teria sido aquele que conseguiu a ajuda do exército para construir as casas e delinear o bairro: "ele pediu ajuda ao regimento para transladar as pessoas, e o regimento mandava cozinheiros, davam café da manhã e almoço enquanto eles faziam sua casa".

Assim, o surgimento de Namqom é relatado segundo múltiplas perspectivas em cujos extremos se situa, por um lado, o reconhecimento da sabedoria e da capacidade de ação coletiva das famílias e, por outro, o nascimento de "pessoas novas", civilizadas graças aos brancos.

Abrimos vários pontos ao longo de nossa análise. Tentaremos agora retomá-los à guisa de conclusão.

\section{Palavras finais}

Neste artigo analisamos a experiência dos Toba qom do Chaco argentino na conquista da cidadania, da terra e do Evangelho, tentando demonstrar que, para uma subjetividade em transformação, a relação dos Qom com os brancos é, por princípio, fundamental para a constituição de si mesmos. Situandoa em uma perspectiva histórica e etnográfica ampla, a migração dos Toba para a periferia de Formosa e a consolidação do bairro Namqom revelam-se parte do processo de constituição da subjetividade individual e coletiva dos Toba do centro-leste do Chaco. Vimos também que, em sua interação com os brancos, eles transitam por uma multiplicidade de esquemas relacionais cuja assimetria pode ser invertida, pois o poder não é investido em um ser instalado nos níveis superiores desses esquemas, mas sim naquele que conta com a possibilidade de "vir a ser outro" graças às reacomodações de relações de poder - e de ser - sempre correlativas. Tais reacomodações não podem ser compreendidas em toda a sua complexidade senão mediante a condição de se identificarem e analisarem os contextos da assimetria com os brancos em uma forma específica de constituição do devir histórico.

As múltiplas perspectivas a partir das quais os Toba interpretam e empreendem a ação estão ligadas a uma teoria específica da ação em que o poder, longe de ser estável, é correlato a um sistema dinâmico e sempre cambiante de relações sociais. Em tal teoria, a agência toba inscreve-se em um campo complexo e multilinear de estratégias e dispositivos destinados a formar, transformar e manter o mundo e as relações entre seus seres, mais que sob o domínio de um poder unilinear, permanente e estável. Estamos diante de uma teoria da ação em que as diferentes perspectivas de leitura permitem, em certos contextos e situações, inverter a assimetria relacional com os brancos. Em suas relações com fazendeiros, missionários e políticos, os Toba fazem 
uso de estratégias e seguem regras de comportamento específicas, como a submissão, a exibição da pobreza ou a demanda por compaixão.

Ao se observarem as diferentes formas pelas quais se constrói o devir histórico, mostramos como a interpretação das experiências a partir de pontos de vista diversos dialoga com um tipo de organização social que promove a constituição de grupos genéricos no sistema de parentesco. Também demonstramos que, através dos relatos dos Toba sobre os brancos - e sem que isto signifique que os primeiros não possam distinguir o humilde do ambicioso ou do trapaceiro entre os segundos - a complexidade entre índios e brancos é reduzida, e as individualidades são realocadas por categorias unitárias. Referindo-se aos Barasana e aos Wâribi, Hugh Jones descreve este contexto como brancos com atributos generalizados e estereotipados em oposição a indígenas igualmente generalizados e estereotipados (1988:141).

Ao estudarmos os múltiplos contextos e as diversas perspectivas a partir das quais se constitui o devir histórico, sinalizamos que a interpretação das experiências desde pontos de vista diversos dialoga também com uma identidade relativa e em devir e com o reconhecimento da primazia da própria experiência e do ponto de vista pessoal.

Sem tratar da saga dos dois irmãos, os relatos toba coincidem com grande parte da mitologia sul-americana ao interpretar o surgimento similar dos brancos e dos índios como a história de uma separação de seres originalmente semelhantes (Renard-Casevitz 1988) e ao evidenciar o paralelismo entre o surgimento dos brancos e sua transformação de afins potenciais (por serem seres da mesma natureza e semelhantes) em inimigos (Hugh Jones 1988:145).

No contexto de uma colonização já realizada, tal inimizade assumiu a forma da assimetria, ao passo que a possibilidade de uma nova afinidade estaria na própria capacidade dos Toba de assumirem um coração "correto", um novo nome, uma nova ocupação, uma nova condição. Em um contexto de identidades e alteridades correlativas, os Toba optaram pela própria transformação para modificar a relação com os brancos, mostrando-se mansos para amansar, mostrando-se carentes para provocar a generosidade, fazendo-se poderosos pela exibição da própria humildade.

Diante de uma assimetria que se expressa cruamente na discriminação, na desigualdade e na exclusão, os jovens de Namqom costumam acusar as primeiras famílias pelo erro de terem firmado as bases de um bairro, hoje um "gueto", no qual "ficaram trancados". Não obstante, os líderes das primeiras famílias recusam-se a reconhecer o erro de que são acusados. O pastor e líder peronista Mendoza conclama os índios a seguirem seu caminho de conquista da cidade, esgueirando-se pouco a pouco pelos interstícios burocráticos, enquanto os brancos, cativados com o exotismo do autóctone, submergem na mata e nos rios: 
Os irmãos brancos desfrutam de nossa comida, prendem as emas e nós ficamos de fora. E nos confinam onde pescamos, não podemos comer mais peixe. Antes os brancos diziam: os índios [são] catinguentos, são porcos porque comem peixe, que nojento, que cheiro ruim! Agora os brancos estão vendendo peixe, já são índios, e nós, graças a Deus, somos filhos de Deus, agora somos novos cristãos. Se estudarmos bastante, se Deus nos ajudar, se der um coração correto aos jovens, quem sabe não entraremos na casa de governo; vamos trabalhar e vamos governar? E estes irmãos brancos vão continuar vendendo peixe. Quem sabe Deus não nos recompensa?

Conquistando o Evangelho, a terra e a cidadania, os Toba tentaram transformar-se em afins de seus inimigos - irmãos, porém distantes - convencidos que estavam da possibilidade de um devir que deixaria os brancos na mata, convertidos nos selvagens que os Toba eram antes, e os índios — por meio de Deus - na casa de governo.

Recebido em 06 de julho de 2007

Aprovado em 30 de julho de 2008

Traduzido por Fernanda Guimarães

Carlos Salamanca é doutor em antropologia social (EHESS 2006), pesquisador associado ao Laboratoire d'Anthropologie et Architecture (Paris-La Villette). E-mail: <salamanca.carlos@gmail.com>

\section{Notas}

* Uma versão preliminar deste trabalho foi apresentada na mesa "Relações Interétnicas" do $8^{\circ}$ Congresso Argentino de Antropologia (2006), coordenada por Karasik, Briones e Krauststokl. Agradeço pelas importantes contribuições e críticas feitas a este trabalho por Gastón Gordillo, Diego Villar, Alexandre Surrallés, César Ceriani e Florencia Tola. Este trabalho foi realizado graças ao apoio do CONICET (Argentina), por meio de uma bolsa de pós-doutorado concedida no período 20062008. As comunidades nas quais realizamos nosso trabalho de campo foram, entre outras, San Carlos, Riacho de Oro, Colonia Aborigen Chaco e Bartolomé de las Casas. San Carlos e Riacho de Oro, localizadas nas proximidades de Subteniente Perín, 200 km a oeste da cidade de Formosa, são habitadas por descendentes de uma mesma 
parcialidade. Colonia Aborigen Chaco, habitada pelos Toba e os Mocoví, situa-se na província do Chaco, a 200 quilômetros de Resistencia, ao sul das localidades de Machagai e Quitilipi. Bartolomé de las Casas fica no centro da província de Formosa, $180 \mathrm{~km}$ a oeste da sua capital.

${ }^{1}$ Os Toba do centro-leste do Chaco argentino entre os quais realizei meu trabalho de campo desde 2001, também chamados "do Chaco oriental", se autodenominam Qom por oposição a docshic (branco) e habitam as atuais províncias de Formosa e do Chaco. Devem ser distinguidos dos Toba-pilagá ou Toba do oeste, entre os quais tanto Métraux $(1937,1946)$ como Karsten (1932) realizaram suas observações e com os quais os Toba do centro-leste mantêm relações muito escassas. O termo toba é a designação oficial daqueles que denominam a si mesmos em língua toba como qom. Toba não corresponde a uma autodesignação, mas a um nome pejorativo de origem guarani que significava frentones ("testudos"). Este termo fazia referência ao costume, hoje em desuso, de se rasparem as sobrancelhas. Apesar de atualmente os Qom reconhecerem a si mesmos como Toba, é preciso mencionar a existência de uma grande diversidade sociopolítica que antecede a utilização deste termo e que hoje em dia também se encontra entre aqueles que são chamados toba. Toba é usado para designar um dos grupos indígenas pertencentes à família linguística guaicuru localizados no Chaco argentino. O termo Qom, pelo contrário, deriva do pronome pessoal da primeira pessoa do plural (qo'omi) e designa, como tal, uma posição relacional. Essa posição abarca, em sentido estrito, aqueles que falam uma mesma língua (qom lactaq, literalmente "a palavra qom") e compartilham certas práticas e representações. Embora os Qom singularizem os diferentes grupos indígenas vizinhos e os de outras regiões, qom é utilizado em sentido amplo também para designar todos os grupos indígenas. Ainda que qom em seu sentido estrito não dê conta da diversidade que existe entre os que se denominam desta maneira, este termo - assim como toba - faz transparecer uma identidade coletiva e étnica englobadora contraposta à sociedade nacional. De fato, o etnônimo qom se opõe à categoria "não-indígena" ou "branco" (docshic). Utiliza-se docshic, em termos gerais, em referência a quem não é nem Toba nem Qom. Os limites dos que se consideram Qom por oposição aos docshic seriam dados por práticas diferenciais ligadas a uma forma específica de apropriação do território, à transmissão oral, ao longo de sucessivas gerações, de conhecimentos, práticas, representações e a uma língua compartilhada, importante marcador identitário.

${ }^{2}$ Os processos de constituição das parcialidades, suas fronteiras e suas territorialidades, assim como as dinâmicas de aliança e cisão são ainda tarefa pendente para a antropologia chaquenha depois do trabalho clássico de Braunstein (1983).

${ }^{3}$ Para isso, baseamo-nos em uma análise sistemática, ainda em curso, que vimos realizando com Florencia Tola desde 2004.

${ }^{4}$ Desde 1940 surgiram no Chaco argentino numerosas igrejas indígenas em torno de líderes carismáticos, pastores indígenas. O evangelismo toba incorporou, desde o início, elementos do cristianismo pentecostal. Os qom desempenharam um papel muito ativo na apropriação dos ensinamentos dos missionários e das mensagens bíblicas, dando lugar a um novo marco religioso e ritual denominado por eles "o Evangelho". Depois do 
trabalho inaugural de Miller (1967), o "Evangelho" foi abordado a partir de múltiplas perspectivas por Lowen, Buckwalter e Kratz 1997 [1965], Miller (1967, 1979), Tola (2004), Wright (1997). Para uma análise das diferentes posturas teóricas, cf. Wright (2002).

${ }^{5}$ Para registrar-se no arquivo de cultos (trâmite obrigatório para toda congregação religiosa não-católica que se estabeleça no país), era e continua sendo preciso preencher um conjunto de formulários, nos quais são respondidas e especificadas diversas questões sobre o tipo de instituição religiosa que se quer inscrever (sua data de fundação, nacionalidade e identidade, número de prosélitos etc.).

${ }^{6}$ Retomo o termo "não-humano" de Descola (2005) para referir-me a uma série de entidades pensadas como existentes (plantas, animais, donos das espécies, fenômenos atmosféricos, espíritos xamânicos, mortos etc.) que os qom consideram e tratam como pessoas (siỹaxaua). A estes seres é imputada uma série de capacidades e atributos semelhantes aos dos seres humanos. Cf. Tola (2004).

${ }^{7}$ Sobre os relatos do surgimento das diferenças entre humanos e animais, cf. Karsten (1932:212-224), Métraux (1946:33), Palavecino (1964:286-289, 1969-70:183), Métraux (1967:146), Cordeu (1969-70:131) e Tomasini (1978-79:67-68).

${ }^{8} \mathrm{O}$ coração, lquiyaqte é na perspectiva toba a sede da vontade, dos pensamentos, das emoções (Tola 2004). Enquanto o sufixo -yaqte indica "o instrumento de", a noção de lqui'i-, comumente traduzida como "alma" ou "espírito", remete à capacidade reflexiva, emotiva e à intencionalidade de qualquer pessoa.

\section{Referências bibliográfícas}

ARIAS, Nora Julia. 2005. Voltas e re-voltas estratégicas dos Tobas rosarinos - de Resistencia a Rosario, Tese de doutorado, Universidade Federal do Rio de Janeiro.

BIGOT, Margot; RODRÍGUEZ, Graciela \& VÁZQUEZ, Héctor. 1992. "Los asentamientos tobas en la ciudad de Rosario". In: J. Radovich \& A. Balazote (orgs.), La problemática indígena. Buenos Aires: CEAL. pp. 81-100.

BONILLA, Oiara. 2005. "O bom patrão e o inimigo voraz: predação e comércio na cosmologia paumari". Mana. Estudos de Antropología Social, 11(1):41-66.
BRAUNSTEIN, José. 1983. "Algunos rasgos de la organización social de los indígenas del Gran Chaco". Trabajos de Etnología, 2:9-102.

CORDEU, Edgardo. 1969-70. "Aproximación al horizonte mítico de los Tobas". Runa, 12(1-2):67-175.

CORDEU, Edgardo \& DE LOS RÍOS, Miguel. 1982. "Un enfoque estructural de las variaciones socioculturales de los cazadores recolectores del Gran Chaco", Suplemento Antropológico, XVII(1):147-160.

DESCOLA, Philippe. 2005. Par-delà nature et culture. Paris: Gallimard. 
FAUSTO, Carlos. 2001. Inimigos fiéis. História, guerra e xamanismo na Amazônia. São Paulo: EdUSP. . 2005. "Se deus fosse jaguar: canibalismo e cristianismo entre os guarani (séculos XVI-XX)". Mana. Estudos de Antropología Social, 11(2):385-418.

GORDILLO, Gastón. 2006. "The crucible of citizenship: ID-paper fetishism in the Argentinean Chaco". American Ethnologist, 2:162-176.

GOW, Peter. 2001. An amazonian myth and its history. Oxford: Oxford University Press.

HARRIS, Olivia. 1995. “'The coming of the white people. Reflections on the mythologisation of history in Latin America". Bulletin of Latin American Research, 14(1):9-24.

HUGH JONES, Stephen. 1988. "The gun and the bow myths of white men and indians". L'Homme, 28(106):138-155.

KARSTEN, Rafael. 1932. Indien tribes of the Argentine and bolivian Chaco. Helsingfors: Societas Scientiarum Fennica.

KELLY, José Antonio. 2005. "Notas para uma teoria do 'virar branco'". Mana. Estudos de Antropología Social, 11(1):201-234.

LEHMANN-NITSCHE, Raphael. 1923. "Mitología sudamericana: la astronomía de los Tobas". Revista del Museo de la Plata, 27:267-285.

LOWEN, Jacob; BUCKWALTER, Albert \& KRATZ, James. 1997 [1965]. "Shamanism, illness, and power in Toba church life". Practical Anthropology, 12:250-280.

MÉTRAUX, Alfred. 1937. "Etudes d'ethnographie Toba-Pilagá (Gran Chaco)". Anthropos, 22:378-401. - 1946. Myths of the Toba and Pilagá indians of the Grand Chaco. Philadelphia: American Folklore Society.

. 1967. Religions et magies indiennes d'Amérique du Sud. Paris: Gallimard.

MILLER, Elmer. 1967. Pentecostalism among the argentine Toba. PhD. Dissertation, University of Pittsburgh.
- 1979. Los Tobas argentinos. Armonía y disonancia en una sociedad. México: Siglo XXI.

RENARD-CASEVITZ, France-Marie. 1988. "L'histoire ailleurs". L'Homme, 28(106):213-225

PALAVECINO, Enrique. 1964. "Notas sobre la mitología chaqueña". Homenaje a Fernando Márquez Miranda, Madrid : Universidad Complutense de Madrid. pp. 284-292. - 1969-70. "Mitos de los índios Tobas". Runa, 12(1-2):177-199.

SALAMANCA, Carlos. 2006. En se glissant dans les fissures de l'utopie. Les Toba aux frontières de l'Etat-nation argentin. Ph.D. Dissertation, EHESS.

SEVERI, Carlo. 2000. "Cosmologia, crise e paradoxo: da imagem de homens e mulheres brancos na tradição xamânica kuna". Mana. Estudos de Antropología Social, 6(1):121-155.

TAMAGNO, Liliana. 1992. "Ser indio hoy: gente toba en la Provincia de Buenos Aires". In: J. Radovich \& A. Balazote (orgs.), La problemática indígena. Buenos Aires: CEAL. pp. 101-116.

TOLA, Florencia. 2004. Je ne suis pas seul(ement) en mon corps. Corps et multiplicité chez les Tobas (qom) du Chaco argentin. Ph.D. Dissertation, EHESS.

TOMASINI, Alfredo. 1978/79. "La narrativa animalística entre los Tobas de occidente". Scripta Ethnologica, 5(1):52-81.

WRIGHT, Pablo. 1997. Being-in-the-dream. Postcolonial explorations in toba ontology. Ph.D. Dissertation, Temple University. · 2002. "L'Evangelio: pentecôtisme indigène en le Chaco argentin". Social Compass, 49(1):43-66.

VILLAR, Diego. 2005. "Indios, blancos y perros". Anthropos, 100(2):495-506. . 2007. "Algunos problemas de interpretación de la religión chané". Bulletin de l'Institut Français d'Études Andines, 36(3):393-405. 


\section{Resumo}

Examinando a experiência dos Toba qom do Chaco argentino na conquista da cidadania, da terra e do Evangelho, analisamos as múltiplas formas de ser qom, evidenciando que, ainda que exista um repertório amplo de possibilidades de ser toba, esse repertório não é infinito. Destacamos que, para uma subjetividade em devir, a relação dos Qom com os brancos é, por princípio, fundamental para a constituição de si mesmo, e evidenciamos que as diferenças "internas" são inerentes ao processo histórico de constituição dos Toba. Analisamos as múltiplas perspectivas de relação com os brancos que surgem a respeito do evento do aparecimento de um bairro periurbano na década de 60, centrando-nos na noção qom de agência e sem nos limitarmos nem às fronteiras geográficas do bairro nem àquelas históricas da relação dos Qom com o Estado-nação. A relação dos Qom com os brancos pode ser traçada como a história de uma separação de seres semelhantes. Propomo-nos demonstrar que, na contracorrente de tal separação, através do Evangelho, da terra e da cidadania e almejando conquistar a igualdade, os Qom tentaram se transformar — novamente — em afins de antigos inimigos.

Palavras-chave Toba, Agência indígena, Ação política, História recente

\section{Abstract}

Examining the experience of the Toba Qom of the Argentinean Chaco in the conquest of citizenship, land and the Gospel, we will analyze the multiple ways of being Qom, making it evident that, although there is an ample repertoire of possible ways of being Toba, this repertoire is not infinite. We stress that, from a subjectivity in becoming, the relationships of the Qom with the whites is, in principle, fundamental in the constitution of the self, and we highlight that "internal" differences are inherent in the historical process of constituting the Toba. We will analyze the multiple perspectives of relations with the whites that emerge in connection to the appearance of a neighbourhood in the urban fringe during the 1960's, focusing on the Qom notions of agency without limiting ourselves either to the geographical frontiers of the neighbourhood or to the historical frontiers of the relationship between the Qom and the Nation State. The relationship of the Qom with the whites can be read as the history of the separation of similar beings. We propose to demonstrate that, in the counter-current of this separation, through the Gospel, land and citizenship, and in seeking the conquest of equality, the Qom have, once again, sought to transform themselves into the affines of former foes.

Key words Toba, Indigenous agency, Political actions, Recent History 